Article

\title{
An FTIR Microspectroscopy Ratiometric Approach for Monitoring X-ray Irradiation Effects on SH-SY5Y Human Neuroblastoma Cells
}

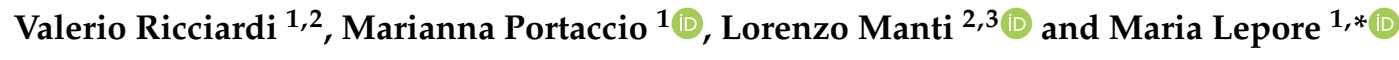 \\ 1 Dipartimento di Medicina Sperimentale, Università della Campania “Luigi Vanvitelli”, 80138 Napoli, Italy; \\ valerio.ricciardi@unicampania.it (V.R.); marianna.portaccio@unicampania.it (M.P.) \\ 2 Istituto Nazionale di Fisica Nucleare - sezione di Napoli, 80100 Napoli, Italy; lorenzo.manti@na.infn.it \\ 3 Dipartimento di Fisica "E. Pancini", Università degli Studi di Napoli “Federico II", 80100 Napoli, Italy \\ * Correspondence: maria.lepore@unicampania.it
}

Received: 11 March 2020; Accepted: 22 April 2020; Published: 24 April 2020

check for updates

\begin{abstract}
The ability of Fourier transform infrared (FTIR) spectroscopy in analyzing cells at a molecular level was exploited for investigating the biochemical changes induced in protein, nucleic acid, lipid, and carbohydrate content of cells after irradiation by graded X-ray doses. Infrared spectra from in vitro SH-SY5Y neuroblastoma cells following exposure to X-rays $(0,2,4,6,8,10 \mathrm{~Gy})$ were analyzed using a ratiometric approach by evaluating the ratios between the absorbance of significant peaks. The spectroscopic investigation was performed on cells fixed immediately ( $\mathrm{t}_{0}$ cells) and $24 \mathrm{~h}$ $\left(t_{24}\right.$ cells) after irradiation to study both the initial radiation-induced damage and the effect of the ensuing cellular repair processes. The analysis of infrared spectra allowed us to detect changes in proteins, lipids, and nucleic acids attributable to X-ray exposure. The ratiometric analysis was able to quantify changes for the protein, lipid, and DNA components and to suggest the occurrence of apoptosis processes. The ratiometric study of Amide I band indicated also that the secondary structure of proteins was significantly modified. The comparison between the results from $t_{0}$ and $t_{24}$ cells indicated the occurrence of cellular recovery processes. The adopted approach can provide a very direct way to monitor changes for specific cellular components and can represent a valuable tool for developing innovative strategies to monitor cancer radiotherapy outcome.
\end{abstract}

Keywords: neuroblastoma cells; Fourier transform infrared microspectroscopy; X-ray radiation; radiation dose effects

\section{Introduction}

Radiation therapy (RT) plays a pivotal role in cancer treatment. Cancer resilience and (hyper)sensitivity of normal tissue to ionizing radiation may lead to local control failure and preclude personalized dose prescriptions (e.g., escalation regimes). Advancements of RT strategies can be obtained by taking into account the large difference in radiosensitivities displayed by both tumor and healthy cells among patients. RT tailoring requires rapid and accurate predictions of cellular radioresponse [1]. For this purpose, many predictive assays have been investigated thus far, but none of them are suitable for routine clinical implementation [2]. Moreover, these biochemical assays used for detecting radiation effects on cellular components can influence the biological samples causing changes in their structure due to chemical substances and elaborated preparation procedures. As a consequence, advances to personalized radiation therapy may benefit from the use of new, non-invasive, and fast optical methods able to examine radiation response in vitro or in vivo across a wide variety of biomolecules. Vibrational techniques such as Raman microspectroscopy [3-5] and Fourier transform infrared microspectroscopy ( $\mu$-FTIR) [6-8] can rapidly and non-invasively investigate biochemical 
components of cells and tissues with minimal sample preparation. These techniques are considered a valuable tool for the analysis of complex biological processes, such as proliferation and cell death process, attracting a growing interest in the field of radiation-induced cyto- and genotoxicity.

In particular, Gault and Lefaix [8] used FTIR spectroscopy to characterize radiation-induced apoptosis in human lymphocytes. The differences between the spectra for apoptotic and control lymphocytes show that the DNA content in the apoptotic cells decreases, while an increase of the bands of amide I and II of protein is visible. These results are in agreement with one of the possible pathways of radiation-induced apoptosis, which is characterized by a slow induction that requires active protein synthesis triggered by the detection of several DNA lesions. These authors showed the ability of the spectroscopy-based technique to distinguish between normal and apoptotic cells at the molecular level and to establish also a temporal scale of the phenomenon $[9,10]$. As previously demonstrated in radiation-induced apoptosis studies, these results show that FTIR, in correlation with established radiobiology techniques, might be useful for assessing early radiation- and oxidative-induced damage to nucleic acids and proteins in single human cells [11].

Meade et al. 2010 [12] performed a chemometric analysis of the variation of IR spectra of the human keratinocytes cell line (HaCaT) exposed to different $\gamma$-radiation doses. They also investigated the effects at different times after irradiation. The observed changes in FTIR spectra features signify a modification of metabolic activity concerning glucose synthesis for energy production in molecular transduction responses to $\gamma$-rays exposure. The absorbance differences in protein amide bands indicate the occurrence of dose-dependent secondary structural changes to protein, already observed by Gault et al. [9-11]. Such changes to protein structure have been proven to result from chain cleavage, formation of protein-protein crosslinks and amino acid degradation after $\gamma$-rays irradiation. In addition, spectral features evidence also a degradation of the structure and function of bio-membranes within the cell.

More recently, Gianoncelli et al. 2015 [13] used infrared spectroscopy to evaluate the effect of X-rays-cells interaction from a different perspective. They attempted to investigate the radiation damage of biological samples that represent a limiting factor when high-resolution X-ray microscopy is performed.

Many different approaches are nowadays available for infrared spectra data pre-processing and analysis as indicated by Baker et al. [6]. Some of the most popular pre-processing procedures are rubber band baseline correction and normalization to the Amide I or Amide II peak [6].

As far as concerns data analysis, many different univariate and multivariate approaches can be adopted [14-16]. In particular, multivariate analysis of infrared spectra collected from human cells exposed to ionizing radiation can allow the identification of the changes at protein, lipid, and amino and nucleic acid level and their dose-dependent behavior [12,17].

As an alternative to these multivariate approaches, some authors suggest that a ratiometric approach can be especially advantageous for highlighting and quantifying biochemical changes in $\mu$-FTIR spectra related to samples in different experimental conditions [18-21]. For example, the protein/lipid ratio can be used to monitor sepsi infection in mice [22] and to differentiate cells in various growth phases [23]. Other properly chosen ratios have been also adopted for discriminating normal, borderline, and malignant ovarian tissues [24]; for comparing red blood cells from gastric cancer tissues [25]; for the early diagnosis of oral cancer [26]; and for monitoring breast cancer progression [27]. Hence, a well-done ratio analysis can indicate valuable spectral biomarkers and can provide a quantitative tool also in many biomedical applications.

In the present work, we chose a ratiometric approach for analyzing $\mu$-FTIR spectra from SH-SY5Y neuroblastoma cells after the exposure to different doses of X-ray $(0,2,4,6,8,10 \mathrm{~Gy})$. This approach can offer a very direct way to monitor changes for specific cellular components. In particular, the spectroscopic investigation has been carried out on cells fixed immediately ( $\mathrm{t}_{0}$ cells) and $24 \mathrm{~h}$ after irradiation ( $\mathrm{t}_{24}$ cells), in order to study both the early effects of the irradiation and those that remain after the cellular repair processes have taken place. The SH-SY5Y cell line is associated with the tumor pathology of greater incidence in infants, and it is the third most common in children, after leukemia and brain cancer [28]. 
In addition, it is of considerable importance in studies aiming to elaborate new approaches for treating and/or preventing disorders of the central nervous system [29-32]. The reported ratiometric analysis of infrared spectra allowed us to detect changes in proteins, lipids, and nucleic acids contributions due to $\mathrm{X}$-ray radiation exposure, as well as to compare the difference arising between $\mathrm{t}_{0}$ and $\mathrm{t}_{24}$ cells.

\section{Materials and Methods}

\subsection{Cell Line}

The cells used in this study are from the SH-SY5Y neuroblastoma cell line (Figure S1). SH-SY5Y is a thrice-cloned (SK-N-SH -> SH-SY -> SH-SY5 -> SH-SY5Y) subline of the neuroblastoma cell line SK-N-SH which was established in 1970 from a metastatic bone tumor (ATCC, Manass, VA, USA). These cells are often used as in vitro models of neuronal function and differentiation (Koriyama et al. 2015). Cells were grown in DMEM medium with the addition of $20 \%$ fetal bovine serum, $1 \%$ of penicillin/streptomycin, and $1 \%$ of L-glutamine and incubated at $37^{\circ} \mathrm{C}, 5 \% \mathrm{CO}_{2}$.

\subsection{Cell Sample Preparation and Treatments}

The cells were seeded on MirrIR slides $\left(25 \times 25 \mathrm{~mm}^{2}\right)($ Kevley Technologies, Chesterland, OH, USA), a specific reflection FT-IR spectroscopy microscope slide, nested in Petri dish capsules. The slides were seeded at a density of about $10^{4} \mathrm{cells} / \mathrm{cm}^{2}$ for a total of approximately $5 \times 10^{6}$ cells/Petri (Figure S2). Such a value for cell density insured both an inter-cell space for the measurement of the background signal without influencing cell survival, as well as the presence of clusters of cells indispensable to acquire a sufficiently intense signal.

X-ray doses were delivered using a STABILIPAN radiogen machine (Siemens, Munich, Germany) equipped with a Thomson tube TR 300F ( $250 \mathrm{kVp}, 1 \mathrm{~mm}$ thick $\mathrm{Cu}$ foil filter, dose rate $0.95 \mathrm{~Gy} / \mathrm{min}$ ). Cellular samples derived from one single frozen vial, in order to avoid variation not deriving from external factors, were exposed to various doses of X-rays. In particular, cells exposed to $2 \mathrm{~Gy}, 4 \mathrm{~Gy}$, $6 \mathrm{~Gy}, 8 \mathrm{~Gy}$, and $10 \mathrm{~Gy}$ were investigated together with unexposed cells (0 Gy) used as a control. Incremental doses of 2 Gy have been chosen, as they are equal to the typical fractions administered daily in radiotherapy treatments. The use of the other doses would allow examining dose-dependent responses. Indeed, these doses are typically used to construct a clonogenic dose-response curve [33]. Right after the exposure, some samples were fixed using paraformaldehyde 3.7\% in Phosphate Buffer Saline (PBS) solution for $20 \mathrm{~min}$ at room temperature. After this, they were washed in distilled water in order to eliminate the residue PBS. Another set of samples, maintained in the culture medium, was re-incubated after irradiation and allowed to recover for $24 \mathrm{~h}$ after exposure before the fixing procedure. Three replicas were prepared for all types of samples. The samples for $\mu$-FTIR were then dried at room temperature and kept in a desiccator until analysis to minimize humidity of the samples. In fact, water molecules are characterized by a strong IR signal. Many authors agree that fixed cells rather than in vivo can be investigated by FTIR spectroscopy $[14,27,34]$. It is much more suitable to work with this kind of samples since the fixing procedure preserves the biochemical properties of the cells after the irradiation and during the measurements.

\subsection{Spectra Acquisition}

IR absorption spectra of the cell samples were obtained using a Spectrum One FTIR (PerkinElmer, Shelton, CT, USA) spectrometer equipped with a Perkin Elmer Multiscope system infrared microscope and an MCT (mercury-cadmium-telluride) FPA (focal-plane-array) detector. The measurements were performed at room temperature on cells grown on $25 \times 25 \mathrm{~mm}^{2}$ MirrIR slides in transreflection mode. For each experimental condition, three slides were prepared. Spectra were acquired within an aperture of $100 \times 100 \mu \mathrm{m}^{2}$. Different regions were investigated on every slide, and three spectra were acquired for each position. The background signal was acquired in a region of the slide free of cells. The signal 
was collected in the spectral region between 3600 and $900 \mathrm{~cm}^{-1}$ using 64 scans with a spectral resolution of $4 \mathrm{~cm}^{-1}$ and a $5 \mathrm{~s}$ acquisition time for each spectrum at room temperature.

\subsection{Data Analysis}

The spectra were preliminarily processed before proceeding with the analysis. Subtraction of background spectrum, acquired in a free-cell zone of the slide was performed. A baseline and excess noise corrections were performed on the whole data set by means of a numerical procedure based on wavelet algorithms ("MATLAB Wavelet Toolbox", MathWorks Inc., Natick, MA, USA) [35-37]. The FTIR signal was represented using the sum of elementary functions (wavelets) at different frequency scales in a hierarchical representation known as the Discrete Wavelet Transform (DWT). Starting from the decomposed parts, the signal can be reconstructed by an inverted process, knows as Inverse Discrete Wavelet Transform (IDWT); removing the last approximation component from the reconstruction process, to eliminate the smoother part of the signal from the spectra. Similarly, by removing the fast frequency components, it is possible to eliminate non-correlated noise signals. In our case, bi-orthogonal wavelets based on the B-spline function were employed for a ten-level decomposition of the signal. The signal was recalculated from detail components up to the nine levels. Average spectra with standard deviation were obtained for all sample types. All the spectra were normalized to have a total area equal to one.

The spectra were analyzed by using convoluted Lorentzian shaped vibrational modes. After a manual selection for the starting conditions of the procedure, a best-fit routine from the Origin software (Version 9.0, OriginLab Corporation, Northampton, MA, USA) was used to determine the optimized intensity, position, and width of the peaks. The $\chi^{2}$ parameter was used for estimating the convolution procedure performance (see [32]). The deconvolution procedure was mainly used for monitoring the changes in the peak position due to $\mathrm{X}$-ray exposure.

The Amide I band was further examined since changes in protein configuration can induce meaningful variations in its characteristics [38-40]. To investigate protein secondary structure, Gauss-cross-Lorentzian shaped components were used for deconvoluting the Amide I band. The inflection points were localized in the second-derivative spectra, using the Savitsky-Golay algorithm (five-data point window) ("GRAMS/AI", Thermo Fischer Scientific, Waltham, MA, USA). The area of each absorption band was considered to be proportional to the relative amount of the structure in infrared spectra [38,41,42].

Further quantitative information about the changes occurring in the infrared spectra related to different experimental conditions was obtained by evaluating the ratios between the absorbance of selected peaks. The list of these ratios, related to protein content, rearrangement, and phosphorylation; DNA content and modification; and lipid content and saturation, is reported in Table 1. The ratio values obtained from the spectra acquired from different samples (different dose, different fixation time) were compared using an un-paired t-test with a $0.05 \%$ significance level.

Table 1. $A_{x} / A_{y}$ indicate the ratio between the absorbance of selected band $[20,39,43-46]$; abbreviation: as $=$ asymmetric, $\mathrm{s}=$ symmetric, $v=$ stretching, $\mathrm{vbr}=$ vibration.

\begin{tabular}{|c|c|c|}
\hline Ratio & \multirow[t]{2}{*}{ Biomolecular Origin } & \multirow[t]{2}{*}{ Indication } \\
\hline $\mathbf{A}_{\mathbf{x}} / \mathbf{A}_{\mathbf{y}}$ & & \\
\hline $\mathrm{A}_{1652} / \mathrm{A}_{1553}$ & Amide I/Amide II- $\alpha$ & Protein rearrangement (PR1) \\
\hline $\mathrm{A}_{1652} / \mathrm{A}_{1527}$ & Amide I/Amide II- $\beta$ & Protein rearrangement (PR2) \\
\hline $\mathrm{A}_{1553} / \mathrm{A}_{2955}$ & Amide II- $\alpha / \mathrm{CH}_{3}$ as. $v$ & Protein/Lipid content (P/L1) \\
\hline $\mathrm{A}_{1652} / \mathrm{A}_{1246}$ & Amide $\mathrm{I} / \mathrm{PO}_{2}^{-}$as. $v$ & Protein/DNA content (P/D1) \\
\hline $\mathrm{A}_{1652} / \mathrm{A}_{1082}$ & Amide $\mathrm{I} / \mathrm{PO}_{2}^{-}$s. $v$ & Protein/DNA content (P/D2) \\
\hline $\mathrm{A}_{1553} / \mathrm{A}_{1527}$ & Amide II- $\alpha /$ Amide II- $\beta$ & Protein rearrangement (PR3) \\
\hline $\mathrm{A}_{2923} / \mathrm{A}_{2955}$ & $\mathrm{CH}_{2}$ as. $v / \mathrm{CH}_{3}$ as. $v$ & Lipid saturation (LS) \\
\hline $\mathrm{A}_{1396} / \mathrm{A}_{2955}$ & $\mathrm{COO}^{-}$s. $v / \mathrm{CH}_{3}$ as. $v$ & Protein/Lipid content (P/L2) \\
\hline $\mathrm{A}_{1246} / \mathrm{A}_{2955}$ & $\mathrm{PO}_{2}{ }^{-}$as. $v, \mathrm{C}-\mathrm{O}-\mathrm{P} v / \mathrm{CH}_{3}$ as. $v$ & Protein phosphorylation (PP1) \\
\hline $\mathrm{A}_{1082} / \mathrm{A}_{2955}$ & $\mathrm{PO}_{2}^{-}$s. $v, \mathrm{C}-\mathrm{O}-\mathrm{P} v / \mathrm{CH}_{3}$ as. $v$ & Protein phosphorylation (PP2) \\
\hline $\mathrm{A}_{1246} / \mathrm{A}_{1082}$ & $\mathrm{PO}_{2}{ }^{-}$as. $\mathrm{N}, \mathrm{C}-\mathrm{O}-\mathrm{P} v / \mathrm{PO}_{2}{ }^{-}$s. $v, \mathrm{C}-\mathrm{O}-\mathrm{P} v$ & DNA modification (DM) \\
\hline
\end{tabular}




\section{Results and Discussion}

\subsection{Features of Infrared Spectra from Control Cells}

In FTIR spectra of SH-SY5Y neuroblastoma cells, several bands related to the vibrational modes of the biologic molecules of cells constituents (lipids, proteins, DNA, etc.) are present. In Figure 1, the average spectrum of an unexposed sample is reported, obtained for the $3600-900 \mathrm{~cm}^{-1}$ spectral region. The spectrum appears to be divided into two principal zones with different visible peaks. The range from 3600 to $2600 \mathrm{~cm}^{-1}$ (Figure 2A,B) is generally indicated as high wavenumber region (HWR) and presents bands that are due to the contribution of proteins, lipids, and carbohydrates. In particular, the bands in the range of $3200-3500 \mathrm{~cm}^{-1}$ are assigned to the amide $A(-\mathrm{N}-\mathrm{H})$ stretching motion of peptide backbones of proteins amino acids and $\mathrm{O}-\mathrm{H}$ stretching of carbohydrate polysaccharides, while the band at $\approx 3150 \mathrm{~cm}^{-1}$ is mainly related to $-\mathrm{NH}_{3}{ }^{+}$asymmetric stretching of free amino acids. The two peaks at $\approx 2960 \mathrm{~cm}^{-1}$ and $\approx 2870 \mathrm{~cm}^{-1}$ are attributed, respectively, to the asymmetric and symmetric stretching of the methyl groups $\left(-\mathrm{CH}_{3}\right)$ given by cellular proteins and lipids contribution. The structures at $\approx 2920 \mathrm{~cm}^{-1}$ and $\approx 2850 \mathrm{~cm}^{-1}$ are, respectively, due to the asymmetric and symmetric stretching of the methylene groups of membrane lipids $\left(-\mathrm{CH}_{2}\right)$.

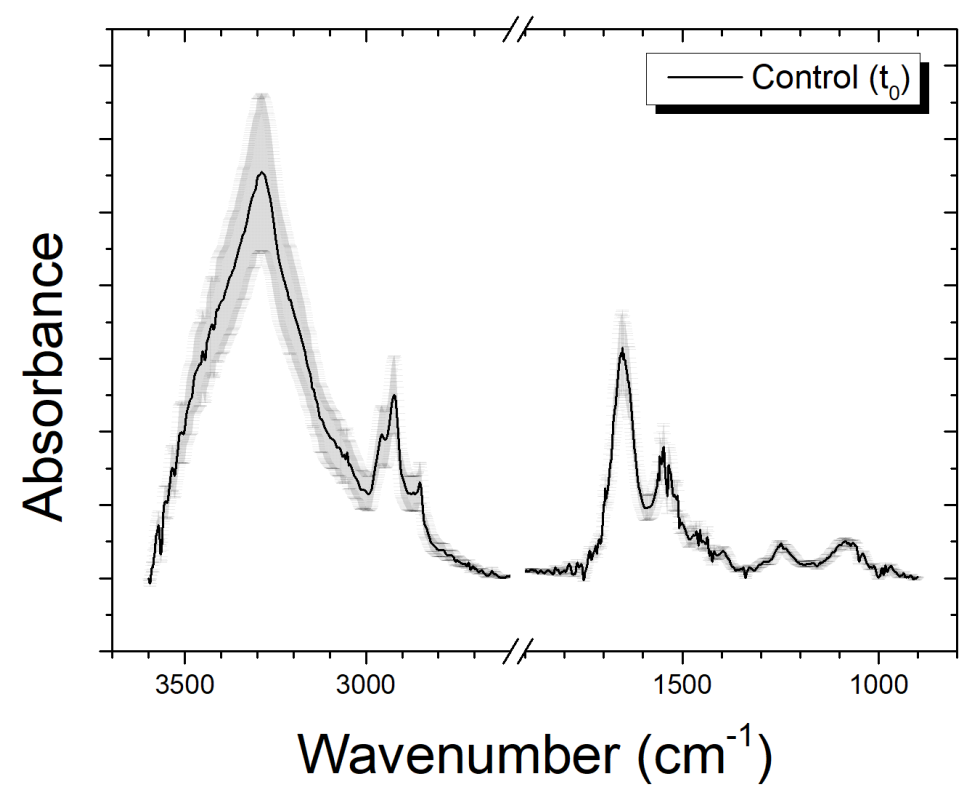

Figure 1. Average spectrum of an unexposed sample in the range $3600-900 \mathrm{~cm}^{-1}$; the break at 2600-1900 $\mathrm{cm}^{-1}$ hides a region without interesting signals from biological molecules; data are presented as $\mathrm{MEAN} \pm \mathrm{SD}$.

In the so-called fingerprint region (1800-900 $\mathrm{cm}^{-1}$ ) (Figure 2C), different peaks that are representative of proteins and nucleic acids are clearly visible. The two peaks at $\approx 1650 \mathrm{~cm}^{-1}$ and $\approx 1540 \mathrm{~cm}^{-1}$ are mainly assigned to the amide $\mathrm{I}(\mathrm{C}=\mathrm{O}$ and $\mathrm{C}-\mathrm{N})$ and amide II $(\mathrm{N}-\mathrm{H}$ and $\mathrm{C}-\mathrm{N})$. The band at $\approx 1450 \mathrm{~cm}^{-1}$ is related to symmetric and asymmetric bending of the methylene and methyl groups $\left(-\mathrm{CH}_{2}\right.$ and $\left.-\mathrm{CH}_{3}\right)$ and to $-\mathrm{CH}_{2}$ scissoring of proteins and lipids, and the peak at $\approx 1400$ is due to $\mathrm{COO}^{-}$group asymmetric stretching of proteins. The asymmetric and symmetric $-\mathrm{PO}_{2}$ stretching vibrations of the phosphodiester nucleic acid backbone are associated with the two bands at $\approx 1240 \mathrm{~cm}^{-1}$ and $\approx 1085 \mathrm{~cm}^{-1}$, respectively, with a contribution from C-O-P stretching of protein and lipids.

The Amide I band (Figure 2D) can be seen as a convolution of the contributions arising from the various secondary structures of proteins; the bands between $1620-1640 \mathrm{~cm}^{-1}$ and $\approx 1690 \mathrm{~cm}^{-1} \mathrm{can}^{-16}$ presumably be assigned to $\beta$-sheet structures with the $\approx 1620$ and $1690 \mathrm{~cm}^{-1}$ band characteristic of the anti-parallel $\beta$-sheet structures. The band at $\approx 1660 \mathrm{~cm}^{-1}$ is mainly attributed to $\alpha$-helix secondary 
structures, while the random structures and $\beta$-turns contribute to the bands at $\approx 1650$ and in the $1670-1685 \mathrm{~cm}^{-1}$ range, respectively.

In Figure 2A-D, the deconvolution for the spectra in the regions $3600-3000 \mathrm{~cm}^{-1}, 3000-2700 \mathrm{~cm}^{-1}$, 2000-600 $\mathrm{cm}^{-1}$, and 1800-1600 $\mathrm{cm}^{-1}$ are, respectively, shown. In Table S1 (Supplementary Material), the assignments for all the resolved peaks are shown [10,12,13,39,47]. In Tables S2 and S3 (Supplementary Material), the assignments for the subcomponents of the Amide I region are shown [37-39].
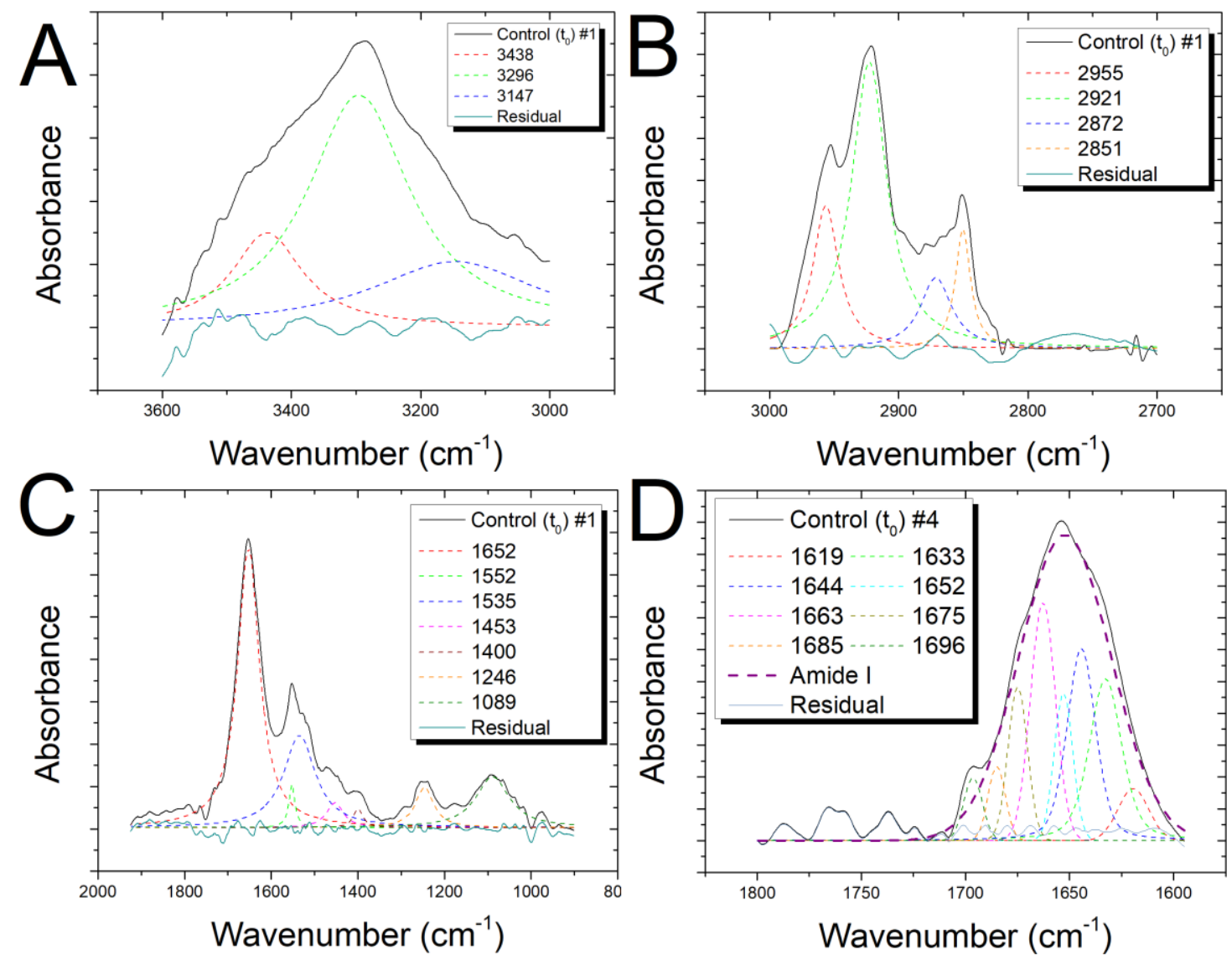

Figure 2. Spectra of one unexposed sample (A) in the range $3600-3000 \mathrm{~cm}^{-1}$, (B) $3000-2700 \mathrm{~cm}^{-1}$, (C) $2000-900 \mathrm{~cm}^{-1}$, and (D) $1800-1600 \mathrm{~cm}^{-1}$ with the results of the deconvolution analysis of peaks using Lorentzian curves and fit residual.

\subsection{Analysis of Infrared Spectra from Cells Fixed Immediately after Irradiation ( $t_{0}$ Cells)}

The average spectra for samples that were exposed to increasing doses of $X$-rays $(0,2,4,6,8$, and $10 \mathrm{~Gy}$ dose, respectively), fixed immediately after irradiation ( $\mathrm{t}_{0}$ cells), are reported in Figure $3 \mathrm{~A}$ for the HWR region and Figure 3B for the fingerprint region, respectively. For both regions, some wavenumber shifts and some differences in peak absorbance are observed in the irradiated sample spectra. In Table 2, the position of peaks for samples exposed to different doses are reported. The shifts, in terms of wavenumber, of peak positions with respect to those found for the control samples are also reported; shifts higher than the spectral resolution of our experimental apparatus are reported in bold character.

For the HWR region, only the peaks at $2870 \mathrm{~cm}^{-1}$, linked to membrane lipids and proteins (assigned to $\mathrm{CH}_{3}$ symmetric stretching) show a shift beyond spectral resolution, at every dose except for the $4 \mathrm{~Gy}$ sample. It must be noted that changes in lipid-related peaks are usually associated with membrane fluidity modifications [43].

In the fingerprint region, shifts are visible for different peaks, mainly in correspondence of higher dose values; that is the case for those at 1553 and $1527 \mathrm{~cm}^{-1}$, both linked to the Amide II proteins 
band, for the 8 and $10 \mathrm{~Gy}$ dose, respectively. The band corresponding to protein $\mathrm{COO}^{-}$symmetric stretching $\left(1396 \mathrm{~cm}^{-1}\right)$ also shows a significant shift at the 8 and $10 \mathrm{~Gy}$ dose. The two bands (located at 1246 and $1082 \mathrm{~cm}^{-1}$ ), mainly associated with $\mathrm{PO}_{2}{ }^{-}$DNA stretching, show shifts at 8 and $10 \mathrm{~Gy}$ and only at $10 \mathrm{~Gy}$, respectively. These wavenumber shifts evidence changes in the lipid, protein, and DNA features of neuroblastoma cells. In particular, the shift of the $\mathrm{PO}_{2}{ }^{-} \mathrm{DNA}$ stretching mode towards higher wavenumber values can be related to changes in the DNA conformation, from the B-DNA form to the A-DNA form. [44]. Moreover, the above-mentioned shifts of Amide II mode can be related to changes in the contributions of the enzymes involved in DNA repair $([48,49]$ and references therein).

Exposure to $X$-rays also induced changes in the absorbance of some peaks. In particular, differences can be seen for the $\mathrm{CH}_{3}$ lipid band at $2870 \mathrm{~cm}^{-1}$ in the HWR region (Figure 3A), in the $1700-1500 \mathrm{~cm}^{-1}$ protein band, and in the DNA bands at 1246 and $1082 \mathrm{~cm}^{-1}$ in the fingerprint region (Figure 3B) for the spectra irradiated with the largest doses $(6,8,10 \mathrm{~Gy})$. These variations will be discussed using a ratiometric method $[18,20,47]$ in the following Section 3.4 .

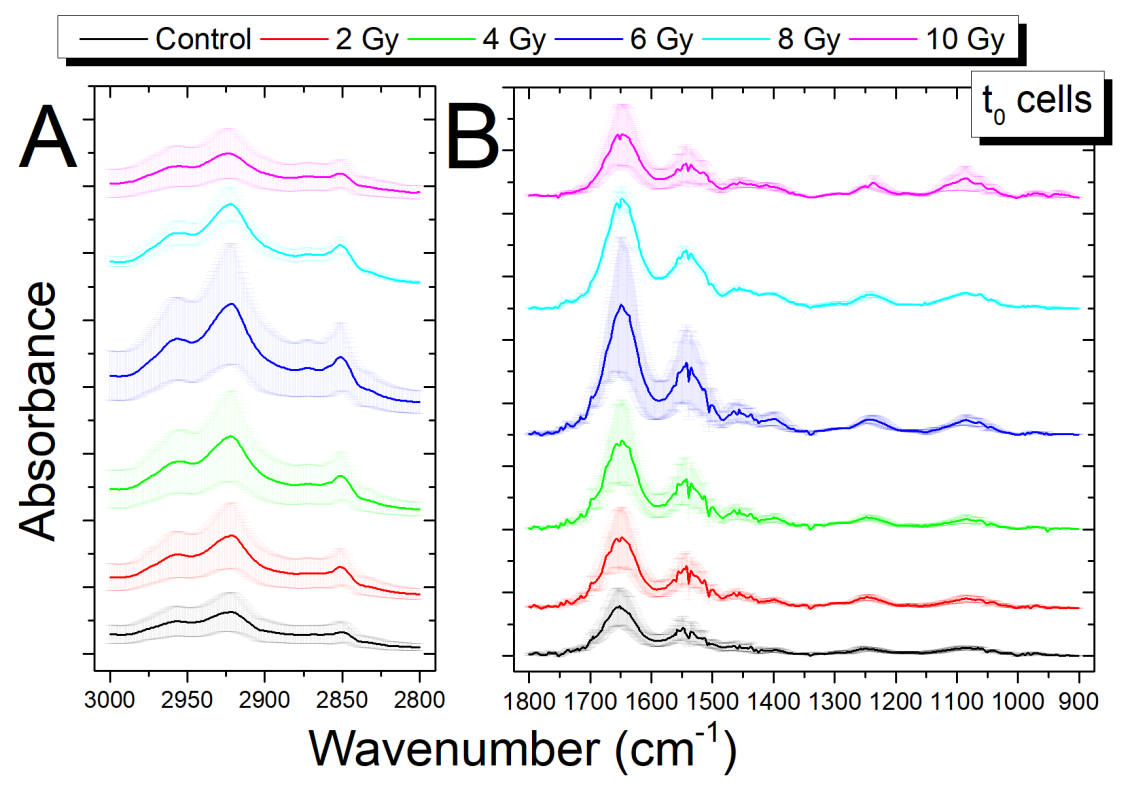

Figure 3. Comparison of average Fourier transform infrared (FTIR) spectra in the region $3000-2700 \mathrm{~cm}^{-1}$ (A) and in the region 1800-900 $\mathrm{cm}^{-1}$ (B) between the control cells (0 Gy) and irradiated cells (2, 4, 6, 8, $10 \mathrm{~Gy}$ ) fixed immediately after irradiation; the spectra are shifted in absorbance to allow the comparison, data are presented as MEAN \pm SD.

\subsection{Analysis of Infrared Spectra from Cells Fixed $24 \mathrm{~h}$ after Irradiation ( $t_{24}$ Cells)}

The average spectra for samples that were exposed to increasing doses of X-rays, fixed $24 \mathrm{~h}$ after irradiation ( $\mathrm{t}_{24}$ cells), are reported in Figure $4 \mathrm{~A}$ for the HWR region and in Figure $4 \mathrm{~B}$ for the fingerprint region, respectively. As in the previous case, they present some wavenumber shifts and some differences in peak absorbance.

In Table 3, the position of peaks for samples exposed to different doses are reported. The shifts, in terms of wavenumber, of peak positions with respect to that found for the unirradiated $t_{24}$ samples are also reported; shifts higher than the spectral resolution available in our experiments are reported in bold characters. 
Table 2. Average FTIR peaks position for control and samples treated with different dose of X-rays fixed immediately after irradiation. The shifts in terms of units of wavenumber are indicated in brackets (bold values stand for shifts greater than the spectral resolution of the instrument $4 \mathrm{~cm}^{-1}$ ). Abbreviations: $\mathrm{p}=$ proteins, $\mathrm{l}=$ lipids, $\mathrm{c}=$ carbohydrates.

\begin{tabular}{|c|c|c|c|c|c|c|}
\hline \multicolumn{7}{|c|}{$\mathbf{t}_{0}$ cells } \\
\hline $0 \mathrm{~Gy}$ & & $2 \mathrm{~Gy}$ & 4 Gy & $6 \mathrm{~Gy}$ & $8 \mathrm{~Gy}$ & $10 \mathrm{~Gy}$ \\
\hline $\begin{array}{c}\text { Peak } \\
\left(\mathrm{cm}^{-1}\right)\end{array}$ & & $\begin{array}{l}\text { Peak } \\
\left(\mathrm{cm}^{-1}\right)\end{array}$ & $\begin{array}{l}\text { Peak } \\
\left(\mathrm{cm}^{-1}\right)\end{array}$ & $\begin{array}{l}\text { Peak } \\
\left(\mathrm{cm}^{-1}\right)\end{array}$ & $\begin{array}{c}\text { Peak } \\
\left(\mathrm{cm}^{-1}\right)\end{array}$ & $\begin{array}{c}\text { Peak } \\
\left(\mathrm{cm}^{-1}\right)\end{array}$ \\
\hline 2955 & $\mathrm{p}, 1$ & $2956(+1)$ & $2957(+2)$ & $2957(+2)$ & $2958(+3)$ & $2959(+4)$ \\
\hline 2922 & 1 & 2922 & 2922 & 2922 & 2922 & $2923(+1)$ \\
\hline 2870 & $\mathrm{p}, 1$ & $2877(+7)$ & $2874(+4)$ & $2885(+15)$ & $2888(+\mathbf{1 8})$ & $2888(+18)$ \\
\hline 2851 & 1 & 2851 & 2851 & 2851 & $2852(+1)$ & $2852(+1)$ \\
\hline 1652 & $\mathrm{p}$ & $1651(-1)$ & $1651(-1)$ & $1649(-3)$ & $1648(-4)$ & $1649(-3)$ \\
\hline 1553 & $\mathrm{p}$ & $1550(-3)$ & $1551(-2)$ & $1550(-3)$ & $1547(-6)$ & $1544(-9)$ \\
\hline 1527 & $\mathrm{p}$ & $1523(-4)$ & $1525(-2)$ & $1528(+1)$ & $1522(-5)$ & $1515(-12)$ \\
\hline 1455 & $\mathrm{p}, 1$ & 1455 & 1455 & $1452(-3)$ & $1451(-4)$ & $1452(-3)$ \\
\hline 1396 & $\mathrm{p}$ & $1398(+2)$ & $1397(+1)$ & $1399(+3)$ & $1402(+6)$ & $1407(+\mathbf{1 1})$ \\
\hline 1246 & DNA, c & $1248(+2)$ & $1247(+1)$ & $1243(-3)$ & $1240(-6)$ & $1241(-5)$ \\
\hline 1082 & DNA & $1081(-1)$ & 1082 & $1084(+2)$ & $1083(+1)$ & $1088(+6)$ \\
\hline
\end{tabular}

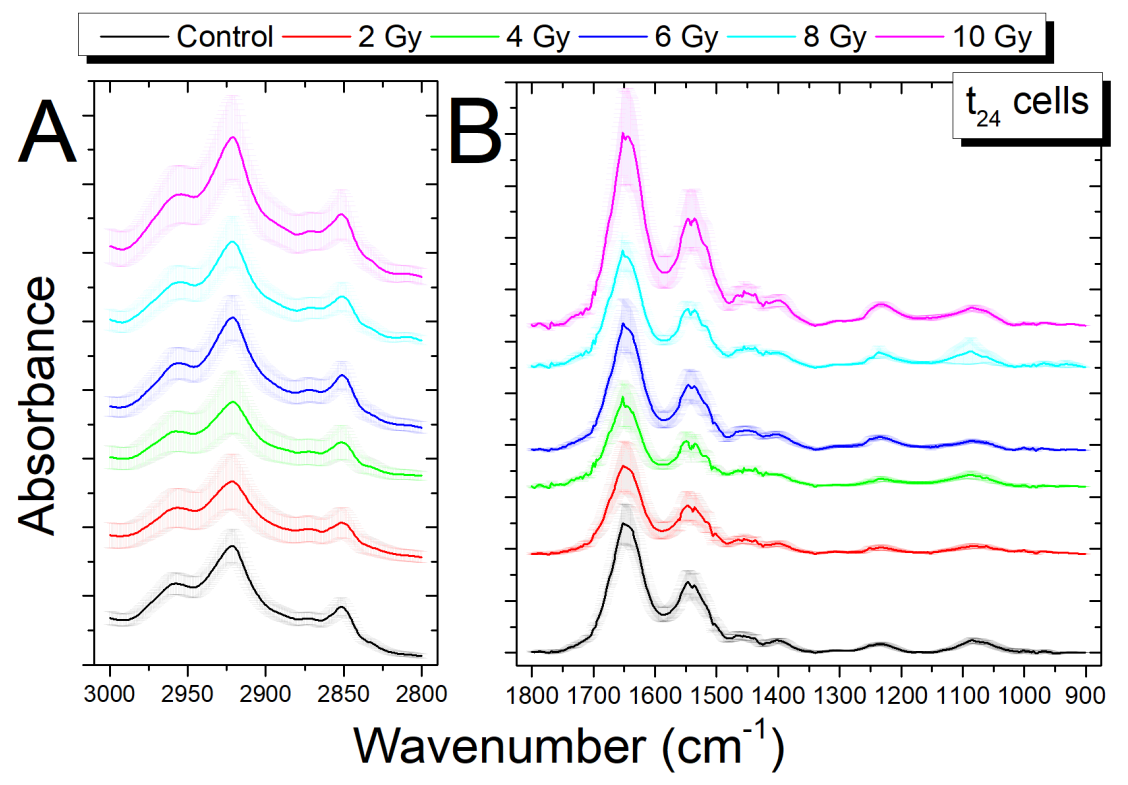

Figure 4. Comparison of average FTIR spectra in the region $3000-2700 \mathrm{~cm}^{-1}(\mathbf{A})$ and in the region $1800-900 \mathrm{~cm}^{-1}$ (B) between the control cells (0 Gy) and irradiated cells (2; 4; 6; 8; $10 \mathrm{~Gy}$ ) fixed $24 \mathrm{~h}$ after irradiation; the spectra are shifted in absorbance to allow the comparison, data are presented as $\mathrm{MEAN} \pm \mathrm{SD}$.

Differently from the $t_{0}$ cells, in the HWR region, there are no significant shifts, while in the fingerprint region, shifts are visible for different peaks. The Amide II band peak $\left(1547 \mathrm{~cm}^{-1}\right)$ shows variations only at $4 \mathrm{~Gy}$, while the peak at $1522 \mathrm{~cm}^{-1}$ changes at all the doses except for $10 \mathrm{~Gy}$; the band at $1452 \mathrm{~cm}^{-1}$, linked to protein and lipid molecule vibrations, shows a shift at $8 \mathrm{~Gy}$ dose. The band at 1235, linked mainly to $\mathrm{PO}_{2}{ }^{-}$DNA stretching, still shows shifts at 4, 8, and $10 \mathrm{~Gy}$; conversely, the band at $1078 \mathrm{~cm}^{-1}$, similarly linked to $\mathrm{PO}_{2}{ }^{-}$DNA stretching, shows shifts for all the doses. As said before, these shifts can be due to changes in the DNA conformation. The difference of the shifts with respect to the $t_{0}$ cells, in which significant shifts are observed only for high doses (8-10 Gy), may offer an 
indication of the evolution, in time, of the damage depending on the type of considered biomolecule, as reported by other researchers [44,48,49].

For $t_{24}$ cells, changes in absorbance of some peaks appears to be less visible for both the HWR and the fingerprint region in comparison with the $t_{0}$ cells changes (see Figure $4 \mathrm{~A}, \mathrm{~B}$ ). These present variations, however, will be discussed using the above-described ratiometric approach $[18,20,47]$ in the following section.

Table 3. Average FTIR peak positions for control and samples treated with different doses of X-rays fixed $24 \mathrm{~h}$ after irradiation. The shifts in terms of units of wavenumber are indicated in brackets for the 0 Gy spectrum stands for shifts with respect to the values found for the control spectrum (t0); bold values stand for shifts greater than the spectral resolution of the instrument $4 \mathrm{~cm}^{-1}$. Abbreviations: $\mathrm{p}=$ proteins, $\mathrm{l}=$ lipids, $\mathrm{c}=$ carbohydrates.

\begin{tabular}{|c|c|c|c|c|c|c|}
\hline \multicolumn{7}{|c|}{$t_{24}$ cells } \\
\hline $0 \mathrm{~Gy}$ & & $2 \mathrm{~Gy}$ & $4 \mathrm{~Gy}$ & $6 \mathrm{~Gy}$ & $8 \mathrm{~Gy}$ & $10 \mathrm{~Gy}$ \\
\hline $\begin{array}{l}\text { Peak } \\
\left(\mathrm{cm}^{-1}\right)\end{array}$ & & $\begin{array}{c}\text { Peak } \\
\left(\mathrm{cm}^{-1}\right)\end{array}$ & $\begin{array}{c}\text { Peak } \\
\left(\mathrm{cm}^{-1}\right)\end{array}$ & $\begin{array}{l}\text { Peak } \\
\left(\mathrm{cm}^{-1}\right)\end{array}$ & $\begin{array}{c}\text { Peak } \\
\left(\mathrm{cm}^{-1}\right)\end{array}$ & $\begin{array}{c}\text { Peak } \\
\left(\mathrm{cm}^{-1}\right)\end{array}$ \\
\hline 2955 & $\mathrm{p}, 1$ & $2959(+4)$ & $2958(+3)$ & $2959(+4)$ & $2958(+3)$ & $2958(+3)$ \\
\hline 2921 & 1 & 2921 & 2921 & $2922(+1)$ & $2922(+1)$ & $2922(+1)$ \\
\hline 2886 & $\mathrm{p}, 1$ & $2883(-3)$ & $2883(-3)$ & $2890(+4)$ & $2890(+4)$ & $2890(+4)$ \\
\hline 2852 & 1 & $2851(-1)$ & $2851(-1)$ & $2851(-1)$ & 2852 & 2852 \\
\hline 1646 & $\mathrm{p}$ & $1648(+2)$ & $1649(+3)$ & $1647(+1)$ & $1648(+2)$ & $1645(-1)$ \\
\hline 1547 & $\mathrm{p}$ & $1549(+2)$ & $1553(+6)$ & $1546(-1)$ & $1550(+3)$ & $1546(-1)$ \\
\hline 1522 & $\mathrm{p}$ & $1528(+6)$ & $1529(+7)$ & $1529(+7)$ & $1527(+5)$ & $1520(-2)$ \\
\hline 1452 & $\mathrm{p}, 1$ & $1450(-2)$ & $1448(-4)$ & $1448(-4)$ & $1447(-5)$ & $1448(-4)$ \\
\hline 1398 & $\mathrm{p}$ & 1398 & $1399(+1)$ & $1400(+2)$ & $1400(+2)$ & 1398 \\
\hline 1235 & DNA, c & $1233(-2)$ & $1225(-10)$ & $1232(-3)$ & $1230(-5)$ & $1229(-6)$ \\
\hline 1078 & DNA & $1071(-7)$ & $1090(+\mathbf{1 2})$ & $1085(+7)$ & $1090(+\mathbf{1 2})$ & $1087(+9)$ \\
\hline
\end{tabular}

\subsection{Analysis of Relative Absorbance Ratios ( $t_{0}$ and $t_{24}$ Cells)}

The intensity of an infrared band is proportional to the concentration of the species that are associated with the band. However, the use of band absorbance values themselves for quantitative analysis can cause experimental artifacts such as variations in sample thickness. For this reason, it is preferable to use their ratios [18-20]. In Table 1, the ratios between the absorbance of selected bands used in this work are reported, with an indication of the biological processes to which they are related.

In Figure 5A-C the ratio values PR1, PR2, and PR3 are reported, for the different doses and times of fixation; all these ratios are mainly related to protein rearrangement (see Table 1). In detail, PR1 is evaluated as the ratio between the absorbance value of the Amide I bands and the $\alpha$-helix subcomponent of Amide II bands; PR2 is estimated as the ratio between the absorbance value of the Amide I band and the absorbance of the $\beta$-sheet subcomponent of Amide II band, and PR3 is given by the ratio of between the absorbance value of the $\alpha$-helix subcomponent and the absorbance of the $\beta$-sheet subcomponent of Amide II band.

The ratio between the absorbance of Amide I and Amide II bands (PR1) shows a significant decrease $(p \leq 0.05)$ at all doses for $t_{0}$ cells, while for the $t_{24}$ cells, values higher than for the 0 Gy sample are shown for all doses, except the 10 Gy one. PR2 shows a decrease for the $t_{0}$ cells, compared to the control, at 6 Gy $(p \leq 0.05)$ and a significant increase at 8 and 10 Gy $(p \leq 0.05)$, while the PR3 ratio shows increasing values for all doses $(p \leq 0.05)$. Conversely, for $t_{24}$ cells, values lower than those of the unirradiated sample are visible for all doses for both ratios. The changes occurring in PR1, PR2, and PR3 values are due to changes in the secondary structure of proteins and can be also correlated with the above-mentioned changes in the contribution of enzymes (that are mainly proteins) involved in DNA repair processes. Further information about the changes in the secondary structure of the protein component of cells will be reported in the following Section 3.5. 
In Figure 6A-E, the ratio values LS, PP1, PP2, P/L1, and P/L2 are reported, respectively, for the different doses and times of fixation. In particular, the LS ratio gives an indication about lipid saturation; PP1 and PP2 ratios are related to protein phosphorylation, while P/L1 and P/L2 ratios report on the relative protein and lipid content (see Table 1).

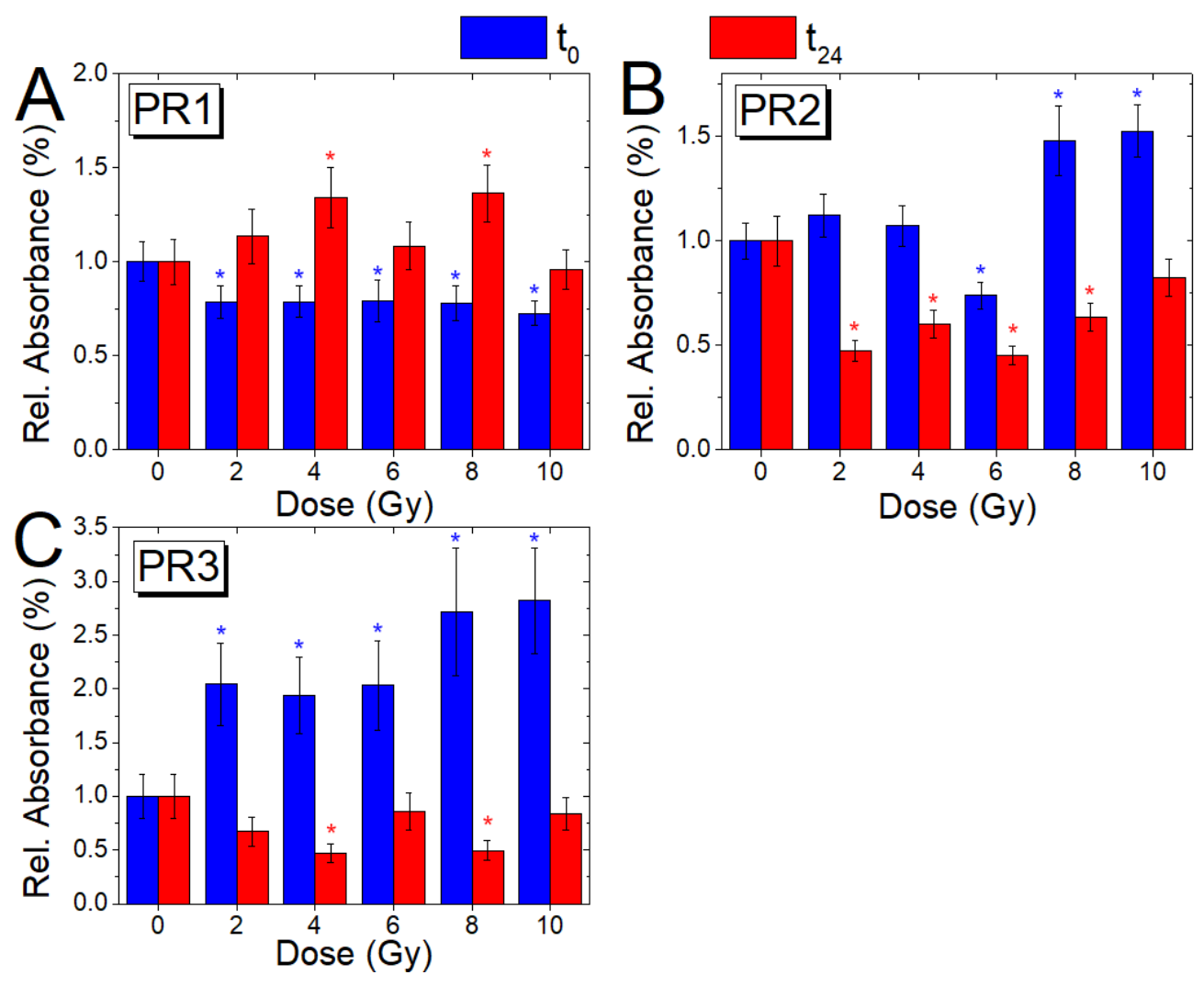

Figure 5. Comparison of the absorbance ratios PR1 (A), PR2 (B), and PR3 (C) with dose, for cells fixed immediately (blue) and $24 \mathrm{~h}$ after irradiation (red); the ratio variations (Mean $\pm \mathrm{SD}$ ) are reported, as a value normalized with respect to the corresponding ratio value of the non-irradiated samples $(0$ $\left.\mathrm{Gy}, \mathrm{t}_{0} ; 0 \mathrm{~Gy}, \mathrm{t}_{24}\right)$; blue and red asterisks indicate when a significant difference in respect to the control value for the $t_{0}$ and $t_{24}$ samples, respectively, occurred at $p \leq 0.05$.

The ratio between the absorbance bands of $\mathrm{CH}_{3}$ and $\mathrm{CH}_{2}$ asymmetric stretching (LS - Figure 6A) evidences a significantly increasing trend with dose, for both $t_{0}$ (for all doses, $p \leq 0.05$ ) and $t_{24}$ cells (for doses higher than $4 \mathrm{~Gy}, p \leq 0.05$ ) indicating an increasing lipid saturation effect $[20,50]$. These modifications can suggest a cell apoptosis process that has been observed to occur together with several membrane changes, such as phosphatidylserine exposure, membrane blebbing, and vesicle formation [46]. Moreover, some researchers noticed an increase in saturated fatty acids containing phospholipids during apoptosis in neuronal cells [45]. Phospholipids are the most important structural components of membranes delimiting many intracellular organelles (e.g., lysosomes, endoplasmic reticulum, and nuclei) and a salient change in their composition could cause deformation and porosity of such membranes. As a consequence, during apoptosis, a characteristic cleavage and laddering of chromosomal DNA occur caused by a deoxyribonuclease flow entering into the nucleus. Singh et al. [51] also suggested that the occurrence of a significant increase in saturated fatty acids only in the apoptotic cells can produce an increase by $10 \%-20 \%$ in saturated fatty acids in a mixed population of apoptotic and non-apoptotic cells. This indication of a possible occurrence of apoptosis is also in agreement with the results of a Raman micro-spectroscopy investigation already reported ([52] and references therein). 

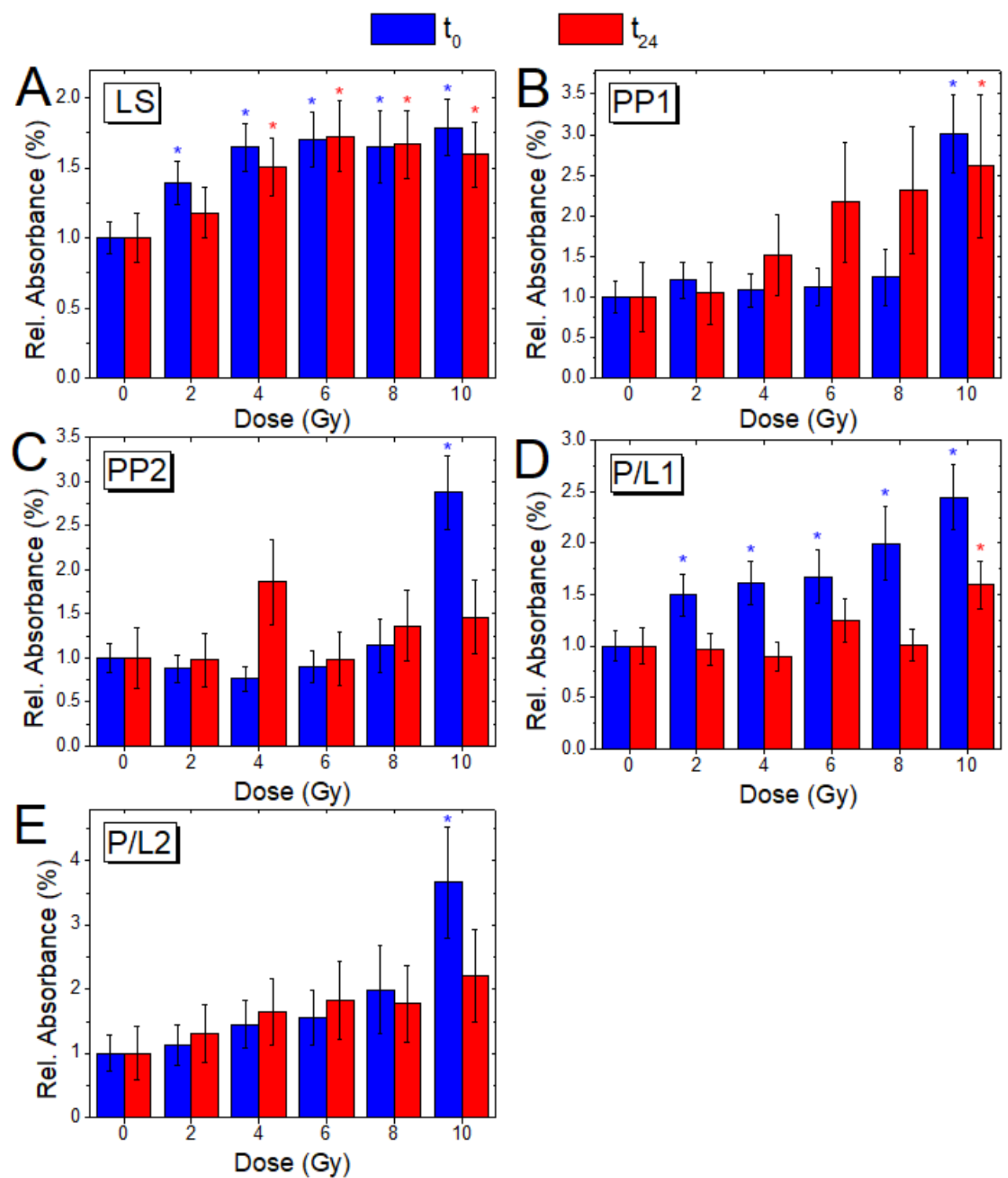

Figure 6. Comparison of the absorbance ratios LS (A), PP1 (B), PP2 (C), PL1 (D) and PL2(E) with dose, for cells fixed immediately (blue) and $24 \mathrm{~h}$ after irradiation (red); the ratio variations (Mean $\pm \mathrm{SD}$ ) are reported, as a value normalized with respect to the corresponding ratio value of the non-irradiated samples $\left(0 \mathrm{~Gy}, \mathrm{t}_{0} ; 0 \mathrm{~Gy}, \mathrm{t}_{24}\right)$; blue and red asterisks indicate when a significant difference in respect to the control value for the $t_{0}$ and $t_{24}$ samples, respectively, occurred at $p \leq 0.05$.

The ratios PP1 (Figure 6B) and PP2 (Figure 6C), which are both linked to protein phosphorylation [53], show significant $(p \leq 0.05)$ modifications only at $10 \mathrm{~Gy}$ for $\mathrm{t}_{0}$ cells. For $\mathrm{t}_{24}$ cells, the ratio PP1 shows an increasing behavior also at 6,8 , and 10 Gy doses which became significant $(p<0.05)$ at 10 Gy while the ratio PP2 does not show a significant trend in the occurring modifications. These modifications confirm the occurrence of changes in the DNA conformation, from the B-DNA form to the A-DNA form already noticed in Sections 3.2 and 3.3 [44,45].

The ratios P/L1 (Figure 6D) and P/L2 (Figure 6E), both linked to cell protein/lipid content, show an increasing trend with the dose for $t_{0}$ cells, which is significant $(p<0.05)$ at all doses and at 10 Gy dose, respectively; on the contrary, $\mathrm{t}_{24}$ samples show a significant shift to a higher value $(p \leq 0.05)$ only for the $\mathrm{P} / \mathrm{L} 2$ ratio at $10 \mathrm{~Gy}$. The analysis of the $\mathrm{P} / \mathrm{L} 1$ and $\mathrm{P} / \mathrm{L} 2$ changes indicates modifications in membrane fluidity and their protein content [43]. 
In Figure 7A-C, ratio values for P/D1, P/D2, and DM are reported, respectively, for the different doses and times of fixation. In this case, the $\mathrm{P} / \mathrm{D} 1$ and $\mathrm{P} / \mathrm{D} 2$ ratios are related to the relative protein and DNA content, while the DM ratio indicates DNA modifications (see Table 1).

The ratio P/D1 (Figure 7A), linked to the ratio between protein and DNA content of the cell, for the $t_{0}$ sample shows an increasing behavior with the dose, which becomes significant at $8 \mathrm{~Gy}(p \leq 0.05)$, and then a marked decrease $(p \leq 0.05)$ for the value at $10 \mathrm{~Gy}$ in respect to the unirradiated sample. Similarly, the ratio P/D2 (Figure 7B), which is associated with similar biological changes, shows an increasing trend $(p \leq 0.05)$ with the dose up to 8 Gy and then a decrease up to values lower than the control at $10 \mathrm{~Gy}(p \leq 0.05)$. The values for $\mathrm{t}_{24}$ cells, instead, show a descending trend for doses higher than $4 \mathrm{~Gy}(p \leq 0.05)$ for the P/D1 ratio and an undefined trend with values significantly $(p \leq 0.05)$ above (6 Gy) and below (4, 8 Gy) compared to the non-irradiated sample for P/D2. The ratio DM (Figure 7C), linked to DNA structure modifications, shows values significantly $(p \leq 0.05)$ higher than the control at low doses (2-6 Gy) for the $t_{0}$ cells and at 6 and 10 Gy for the $t_{24}$ cells.
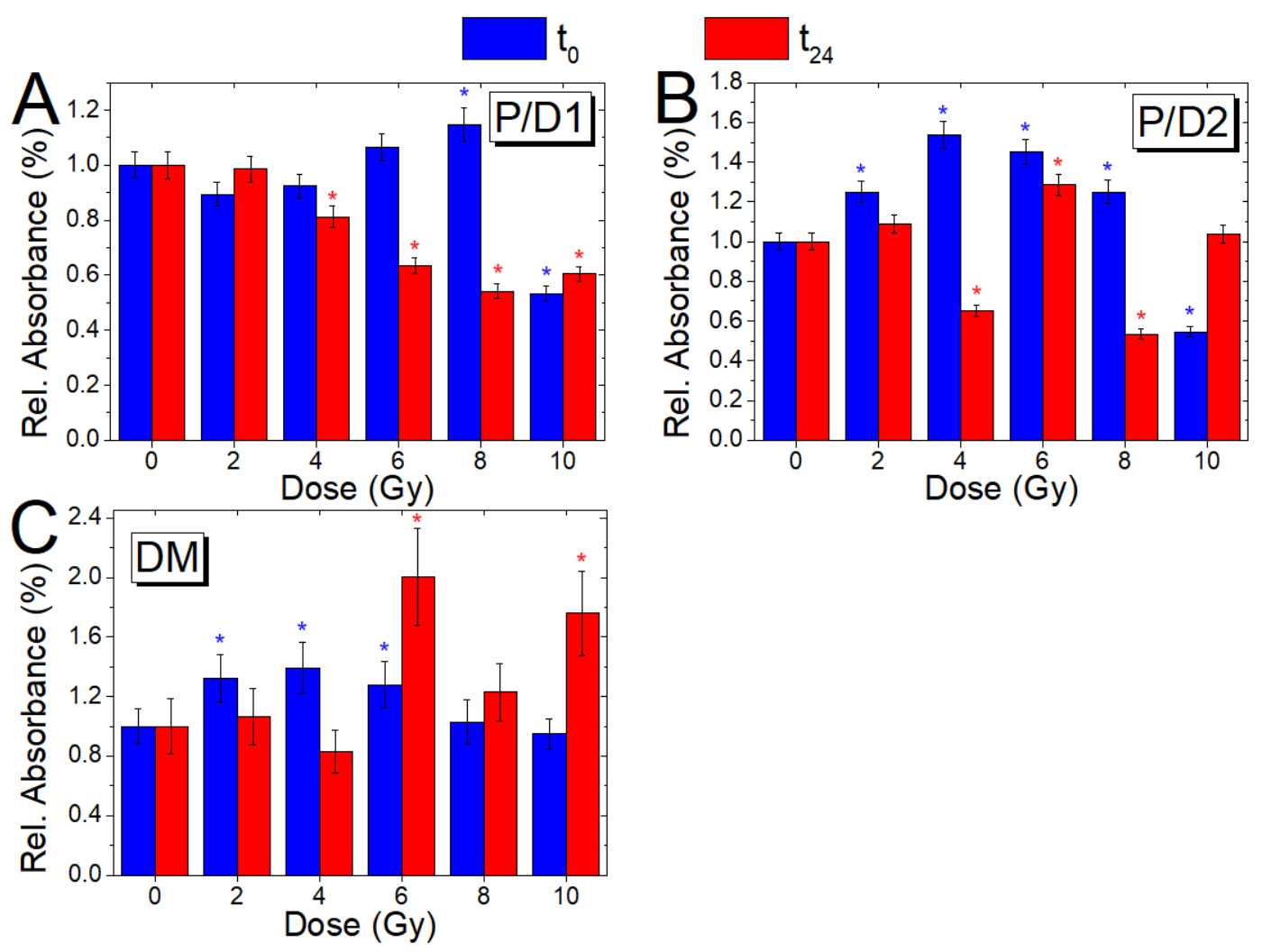

Figure 7. Comparison of the absorbance ratios P/D1 (A), P/D2 (B), and DM (C) with dose, for cells fixed immediately after (blue) and $24 \mathrm{~h}$ after irradiation (red); the ratio variations (Mean $\pm \mathrm{SD}$ ) are reported as a value normalized with respect to the corresponding ratio value of the non-irradiated samples $\left(0 \mathrm{~Gy}, \mathrm{t}_{0} ; 0 \mathrm{~Gy}, \mathrm{t}_{24}\right)$; blue and red asterisks indicate when a significant difference in respect to the control value for the $t_{0}$ and $t_{24}$ samples, respectively, occurred at $p \leq 0.05$.

The modifications evidenced by $\mathrm{P} / \mathrm{D} 1, \mathrm{P} / \mathrm{D} 2$, and $\mathrm{DM}$ are in agreement with the results obtained in other cell systems exposed to ionizing radiation that indicate the occurrence of damage in the primary, secondary, and tertiary structure of nucleic acid [54].

\subsection{Analysis of Amide I Band ( $t_{0}$ and $t_{24}$ Cells)}

The analysis of the different peaks constituting the Amide I band can offer precise information on the secondary structure of proteins and their conformational changes as a result of different doses of ionizing radiation. In the present case, the Amide I band of control samples and irradiated samples was 
analyzed using eight subcomponents related to parallel $\beta$-sheet $\left(1626,1635 \mathrm{~cm}^{-1}\right)$, anti-parallel $\beta$-sheet $\left(1617,1697 \mathrm{~cm}^{-1}\right), \alpha$-helix $\left(1661 \mathrm{~cm}^{-1}\right)$, and $\beta$-turn $\left(1674 \mathrm{~cm}^{-1}\right)$; unordered structures are attributed to the band at $1646 \mathrm{~cm}^{-1}$. In Figure $8 \mathrm{~A}, \mathrm{~B}$, the ratios between the secondary structures peak area, grouped according to the different structures, and the area of the entire Amide I peak, as a percentage, are reported for both $t_{0}$ and $t_{24}$ cells, respectively. In particular, the $\beta$-sheet bar is related to the contributions of different $\beta$-sheet subcomponents that are reported in Tables S2 and S3 (Supplementary Material) in terms of percentage of the areas together with the other subcomponent bands for $t_{0}$ and $t_{24}$ samples. As already indicated by the PR1, PR2, and PR3 analysis reported in Section 3.4, the exposure to $\mathrm{X}$-rays induces several modifications in protein secondary structure. More specifically, a significant increase $(p \leq 0.05)$ for the $\beta$-sheet structure is visible for all the $t_{0}$ irradiated samples combined with a decrease in the signal coming from the $\alpha$-helix structure; for both, the structure the maximum/minimum, respectively, occurs at 6 Gy. Moreover, for the $t_{0}$ cells, the $\beta$-turn structure shows modification at 2, 4, 6, and $8 \mathrm{~Gy}$, with values higher than the control sample while the unordered component has lower values than the control for all doses. The ratios for $t_{24}$ cells show a stable course for all the sub-structures with significant variations $(p \leq 0.05)$ only at the maximum dose of $10 \mathrm{~Gy}$; in fact, a shift towards lower values of the $\beta$-sheet structure band is accompanied by an increase in the percentage linked to the $\alpha$-helix band and of the unordered structure.
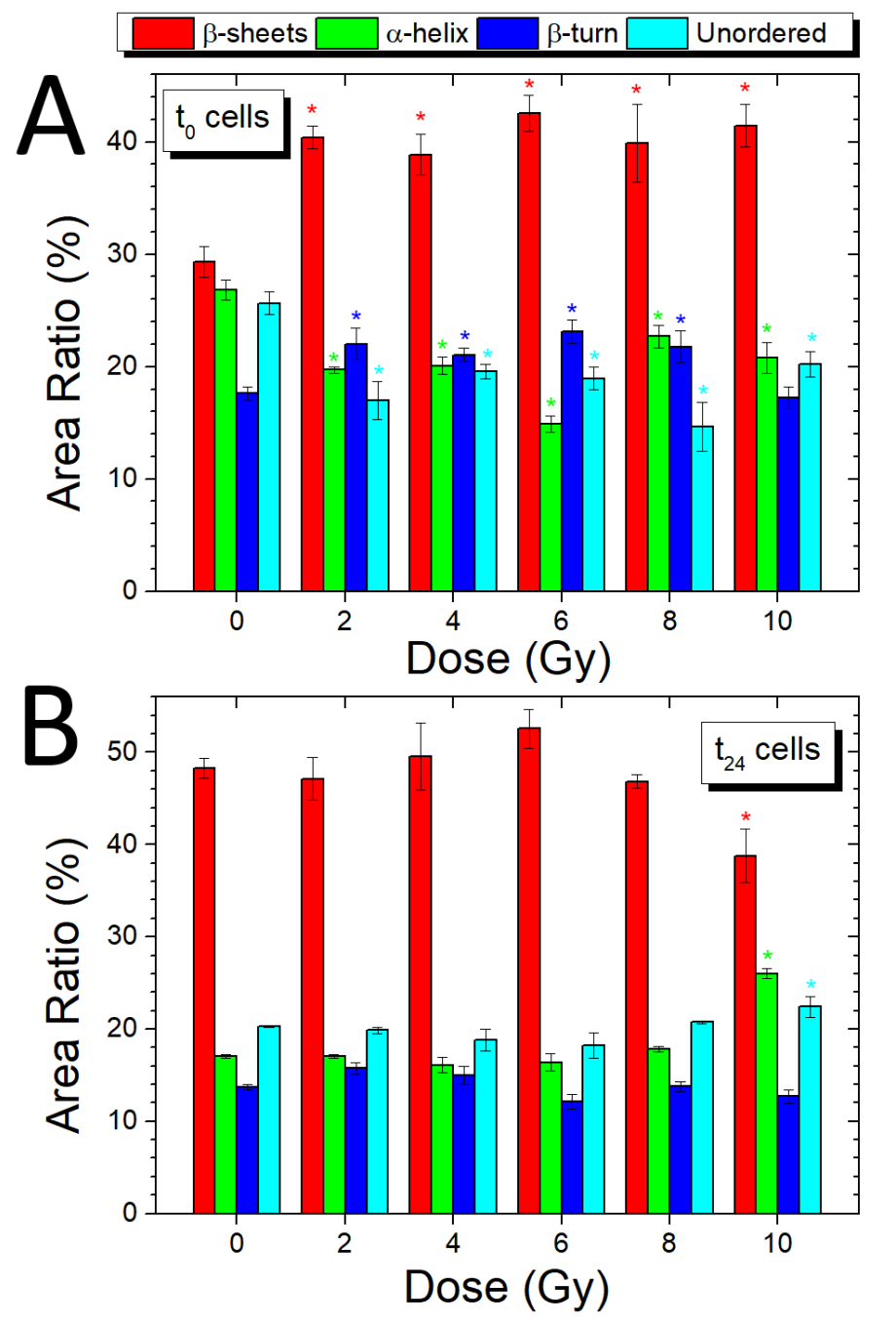

Figure 8. Variations of secondary protein structure contributions to Amide I band (1590-1710 $\mathrm{cm}^{-1}$ ) with dose, for cells fixed immediately (A) and $24 \mathrm{~h}$ after irradiation (B); the ratios between the secondary structures peaks area and the area of the entire Amide I peak are reported; asterisks of different colors indicate when a significant difference in respect to the corresponding control value occurred at $p \leq 0.05$. 


\section{Conclusions}

FTIR analyses have been performed on SH-SY5Y neuroblastoma cells to examine the compositional, structural, and functional changes that take place in cell structure as a result of exposure to X-ray radiation. The infrared spectra that were obtained from unexposed and exposed cells show significant differences. In particular, changes in the peak position and intensity were observed for $\mathrm{CH}_{3}$ symmetric stretching, indicating the occurrence of modifications of membrane fluidity. The reported shifts of the $\mathrm{PO}_{2}{ }^{-}$DNA stretching mode towards higher wavenumber values can be associated with changes in the DNA conformation. Moreover, the shifts of Amide II mode can be related to changes in the contributions of the enzymes involved in DNA repair. These changes are especially evident for the largest X-ray doses in the spectra from cells fixed immediately after the irradiation. The proposed approach by using the ratios between the absorbance of significant peaks was also able to quantify changes for the protein, lipid, and DNA components. In particular, the changes in the protein rearrangement-related ratios (PR1, PR2, and PR3) are ascribed to changes in the secondary structure of proteins and can be also correlated with the changes in the contribution of enzymes involved in DNA repair processes mentioned above. The ratiometric study of the Amide I band confirmed that the secondary structure of proteins was significantly modified by $\mathrm{X}$-ray exposure. In addition, the changes for ratio between the absorbance bands of $\mathrm{CH}_{3}$ and $\mathrm{CH}_{2}$ asymmetric stretching (LS) suggested the occurrence of a cell apoptosis process. Moreover, the ratios between protein and lipid contents (P/L1 and P/PL2) showed significant differences that can be related to changes in membrane configuration. The comparison between the ratio values for $t_{0}$ and $t_{24}$ also showed the occurrence of cellular recovery processes.

The present results confirm once more that $\mu$-FTIR is a powerful tool for detecting and studying X-ray-induced effects in human cells. Its sensitivity makes this spectroscopy technique one the most accurate tools for the simultaneous detection of various functional groups. In doing so, $\mu$-FTIR enables the evaluation of global changes more than the quantification of a single biomarker as usually done by conventional biochemical assays. Then our results can be useful for developing novel methodologies to monitor cancer radiotherapy outcomes to decrease the overall radiation dose, thus, minimizing damage to the nearby healthy cells, which is very important for early and late-occurring adverse effects.

Supplementary Materials: The following are available online at http://www.mdpi.com/2076-3417/10/8/2974/s1, Table S1: FT-IR peaks observed in the spectrum of control cells, with assignments in accordance with the data reported in the literature $[10,12,13,39,44]$ abbreviation: as = asymmetric, $s=$ symmetric, $v=$ stretching, $\delta=b e n d i n g$, $\mathrm{sc}=$ scissoring, $\mathrm{vbr}=$ vibration, $\mathrm{a}$. a. = free amino acids. The indicated position of every peak is the center of the relative Lorentzian function obtained from the deconvolution fit, Table S2: Amide I deconvolution results for control and irradiated sample fixed immediately after irradiation, with assignments in accordance with the data reported in the literature [37-39]; the ratio between the secondary structures peaks area and the area of the entire Amide I peak, as a percentage, are reported in the table, Table S3: Amide I deconvolution results for control and irradiated sample fixed $24 \mathrm{~h}$ after irradiation, with assignments in accordance with the data reported in the literature [37-39]; the ratio between the secondary structures peaks area and the area of the entire Amide I peak, as a percentage, are reported in the table, Figure S1: SH-SY5Y cells at different culture density (ATCC, American type culture collection), Figure S2: Micrograph at 10× magnification of SH-SY5Y cells control sample adherent to the MirrIR slide. A cells cluster is visible in the brighter area that is manually selected for collecting the signal for Fourier transform infrared (FTIR) spectroscopy.

Author Contributions: Conceptualization, V.R. and M.L.; methodology, M.P. and L.M.; software, V.R. and M.P.; formal analysis, V.R. and M.L.; investigation, V.R., M.P. and M.L.; data curation, V.R. and M.P.; writing-original draft preparation, V.R.; writing-review and editing, M.P. and M.L. All authors have read and agreed to the published version of the manuscript.

Funding: This research received no external funding.

Acknowledgments: The authors are pleased to thank I. Delfino for fruitful discussions.

Conflicts of Interest: The authors declare no conflict of interest. 


\section{References}

1. Coates, A.S.; Winer, E.P.; Goldhirsch, A.; Gelber, R.D.; Gnant, M.; Piccart-Gebhart, M. Panel Members. Tailoring therapies improving the management of early breast cancer: St Gallen International Expert Consensus on the primary therapy of early breast Cancer 2015. Ann. Oncol. 2015, 26, 1533-1546. [CrossRef] [PubMed]

2. Story, M.D.; Durante, M. Radiogenomics. Med. Phys. 2018, 4, e1111-e1122. [CrossRef] [PubMed]

3. Kong, K.; Kendall, C.; Stone, N.; Notingher, I. Raman spectroscopy for medical diagnostics: From in vitro biofluid assays to in-vivo cancer detection. Adv. Drug Deliv. Rev. 2015, 89, 121-134. [CrossRef] [PubMed]

4. Butler, H.J.; Ashton, L.; Bird, B.; Cinque, G.; Curtis, K.; Dorney, J.; Esmonde-White, K.; Fullwood, N.J.; Gardner, B.; Martin-Hirsch, P.L.; et al. Using Raman spectroscopy to characterize biological materials. Nat. Protoc. 2016, 11, 664-687. [CrossRef] [PubMed]

5. Pence, I.; Mahadevan-Jansen, A. Clinical instrumentation and applications of Raman spectroscopy. Chem. Soc. Rev. 2016, 45, 1958-1979. [CrossRef] [PubMed]

6. Baker, M.J.; Trevisan, J.; Bassan, P.; Bhargava, R.; Butler, H.J.; Dorling, K.M.; Fielden, P.R.; Fogarty, S.W.; Fullwood, N.J.; Heys, K.A.; et al. Using Fourier transform IR spectroscopy to analyze biological material. Nat. Protoc. 2014, 9, 1771-1791. [CrossRef]

7. Lovergne, L.; Bouzy, P.; Untereiner, V.; Garnotel, R.; Baker, M.J.; Thiefin, G.; Sockalingum, G.D. Biofluid infrared spectro-diagnostics: Pre-analytical considerations for clinical applications. Faraday Discuss 2016, 187, 521-537. [CrossRef]

8. Sakudo, A. Near-infrared spectroscopy for medical applications: Current status and future perspectives. Clin. Chim. Acta 2016, 455, 181-188. [CrossRef]

9. Gault, N.; Lefaix, J.L. Infrared microspectroscopic characteristics of radiation-induced apoptosis in human lymphocytes. Radiat. Res. 2003, 160, 238-250. [CrossRef]

10. Gasparri, F.; Muzio, M. Monitoring of apoptosis of HL60 cells by Fourier-transform infrared spectroscopy. Biochem. J. 2003, 369, 239-248. [CrossRef]

11. Gault, N.; Rigaud, O.; Poncy, J.L.; Lefaix, J.L. Infrared microspectroscopy study of $\gamma$-irradiated and $\mathrm{H}_{2} \mathrm{O}_{2}$-treated human cells. Int. J. Radiat. Biol. 2005, 81, 767-779. [CrossRef] [PubMed]

12. Meade, A.; Clarke, C.; Byrne, H.; Lyng, F. Fourier transform infrared microspectroscopy and multivariate methods for radiobiological dosimetry. Radiat. Res. 2010, 173, 225-237. [CrossRef] [PubMed]

13. Gianoncelli, A.; Vaccari, L.; Kourousias, G.; Cassese, D.; Bedolla, D.E.; Kenig, S.; Storici, P.; Lazzarino, M.; Kiskinova, M. Soft X-ray microscopy radiation damage on fixed cells investigated with synchrotron radiation FTIR microscopy. Sci. Rep. 2015, 5, 10250. [CrossRef] [PubMed]

14. Larrechi, M.; Callao, M. Strategy for Introducing NIR Spectroscopy and Multivariate Calibration Techniques in Industry. Trends Anal. Chem. 2003, 22, 634-640. [CrossRef]

15. Xiaobo, Z.; Jiewen, Z.; Povey, M.J.; Holmes, M.; Hanpin, M. Variables Selection Methods in Near-Infrared Spectroscopy. Anal. Chim. Acta 2010, 667, 14-32. [CrossRef] [PubMed]

16. Gautam, R.; Vanga, S.; Ariese, F.; Umapathy, S. Review of multidimensional data processing approaches for Raman and infrared spectroscopy. EPJ Technol. Instrum. 2015, 2, 8. [CrossRef]

17. Lipiec, E.; Birarda, G.; Kowalska, J.; Lekki, J.; Vaccari, L.; Wiecheć, A.; Wood, B.R.; Kwiatek, W.M. A new approach to studying the effects of ionising radiation on single cells using FTIR synchrotron microspectroscopy. Radiat. Phys. Chem. 2013, 93, 135-141. [CrossRef]

18. Gautam, R.; Chandrasekar, B.; Deobagkar-Lele, M.; Rakshit, S.; Umapathy, S.; Nandi, D. Identification of early biomarkers during acetaminophen-induced hepatotoxicity by Fourier transform infrared microspectroscopy. PLoS ONE 2012, 7, e45521. [CrossRef]

19. Li, J.Y.; Ying, G.G.; Jones, K.C.; Martin, F.L. Real-world carbon nanoparticle exposures induce brain and gonadal alterations in zebrafish (Danio rerio) as determined by biospectroscopy techniques. Analyst 2015, 140, 2687-2695. [CrossRef]

20. Kumar, S.; Verma, T.; Mukherjee, R.; Ariese, F.; Somasundaram, K.; Umapathy, S. Raman and infrared microspectroscopy: Towards quantitative evaluation for clinical research by ratiometric analysis. Chem. Soc. Rev. 2016, 45, 1879-1900. [CrossRef]

21. Bel'skaya, L.V. Use of IR spectroscopy in cancer diagnosis. A review. J. Appl. Spectrosc. 2019, 86, 187-205. [CrossRef] 
22. Gautam, R.; Deobagkar-Lele, M.; Majumdar, S.; Chandrasekar, B.; Victor, E.; Ahmed, S.M.; Wadhwa, N.; Verma, T.; Kumar, S.; Sundaresan, N.R.; et al. Molecular profiling of sepsis in mice using Fourier Transform Infrared Microspectroscopy. J. Biophotonics 2016, 9, 67-82. [CrossRef] [PubMed]

23. Mourant, J.R.; Yamada, Y.; Carpenter, S.; Dominique, L.; Freyer, J. FTIR spectroscopy demonstrates biochemical differences in mammalian cell cultures at different growth stages. Biophys. J. 2003, 85, 1938-1947. [CrossRef]

24. Theophilou, G.; Lima, K.L.M.; Martin-Hirsch, P.L.; Stringfellow, H.F.; Martin, F.L. ATR-FTIR spectroscopy coupled with chemometric analysis discriminates normal, borderline and malignant ovarian tissue: Classifying subtypes of human cancer. Analyst 2016, 141, 585-594. [CrossRef] [PubMed]

25. Liu, H.; Su, Q.; Sheng, D.; Zheng, W.; Wang, X. Comparison of red blood cells from gastric cancer patients and healthy persons using FTIR spectroscopy. J. Mol. Struct. 2017, 1130, 33-37. [CrossRef]

26. Adeeba; Siddiqui, A.J.; Sherazi, S.T.H.; Ahmed, S.; Choudhary, M.I.; Atta-ur-Rahman; Musharraf, S.G. A comparative profiling of oral cancer patients and high risk niswar users by using FT-IR and chemometric analysis. Spectrochim. Acta Part A Mol. Biomol. Spectrosc. 2018, 203, 177-184. [CrossRef]

27. Kar, S.; Katti, D.R.; Katti, K.S. Fourier transform infrared spectroscopy based spectral biomarkers of metastasized breast cancer progression. Spectrochim. Acta Part. A Mol. Biomol. Spectrosc. 2019, 208, 85-96. [CrossRef]

28. Maris, J.M.; Hogarty, M.D.; Bagatell, R.; Cohn, S.L. Neuroblastoma. Lancet 2007, 369, 2106-2120. [CrossRef]

29. Encinas, M.; Iglesias, M.; Liu, Y.; Wang, H.; Muhaisen, A.; Gallego Ceña, C.; Comella, J.X. Sequential treatment of SH-SY5Y cells with retinoic acid and brain-derived neurotrophic factor gives rise to fully differentiated, neurotrophic factor-dependent, human neuron-like cells. J. Neurochem. 2000, 75, 991-1003. [CrossRef]

30. Jämsä, A.; Hasslund, K.; Cowburn, R.F.; Bäckström, A.; Vasänge, M. The retinoic acid and brain-derived neurotrophic factor differentiated SH-SY5Y cell line as a model for Alzheimer's disease-like tau phosphorylation. Biochem. Biophys. Res. Commun. 2004, 319, 993-1000. [CrossRef]

31. Agholme, L.; Lindström, T.; Kågedal, K.; Marcusson, J.; Hallbeck, M. An in vitro model for neuroscience: Differentiation of SH-SY5Y cells into cells with morphological and biochemical characteristics of mature neurons. J. Alzheimers Dis. 2010, 20, 1069-1082. [CrossRef] [PubMed]

32. Koriyama, Y.; Furukawa, A.; Muramatsu, M.; Takino, J.; Takeuchi, M. Glyceraldehyde caused Alzheimer's disease-like alterations in diagnostic marker levels in SH-SY5Y human neuroblastoma cells. Sci. Rep. 2015, 5, 13313. [CrossRef] [PubMed]

33. Puck, T.T.; Marcus, P.I. Action of x-rays on mammalian cells. J. Exp. Med. 1956, 103, 653-666. [CrossRef] [PubMed]

34. Clemens, G.; Hands, J.R.; Dorling, K.M.; Baker, M.J. Vibrational spectroscopic methods for cytology and cellular research. Analyst 2014, 139, 4411-4444. [CrossRef] [PubMed]

35. Camerlingo, C.; Zenone, F.; Gaeta, G.M.; Riccio, R.; Lepore, M. Wavelet data processing of micro-Raman spectra of biological samples. Meas. Sci. Technol. 2006, 17, 298-303. [CrossRef]

36. Camerlingo, C.; Zenone, F.; Perna, G.; Capozzi, V.; Cirillo, N.; Gaeta, G.M.; Lepore, M. An investigation on micro-Raman spectra and wavelet data analysis for pemphigus vulgaris follow-up monitoring. Sensors 2008, 8, 3656-3664. [CrossRef]

37. Delfino, I.; Perna, G.; Lasalvia, M.; Capozzi, V.; Manti, L.; Camerlingo, C.; Lepore, M. Visible micro-Raman spectroscopy of single human mammary epithelial cells exposed to X-ray radiation. J. Biomed. Opt. 2015, 20, 035003. [CrossRef]

38. Pelton, J.T.; McLean, L.R. Spectroscopic Methods for Analysis of Protein Secondary Structure. Anal. Biochem. 2000, 277, 167-176. [CrossRef]

39. Barth, A. Infrared spectroscopy of proteins. Biochim. Biophys. Acta 2007, 1767, 1073-1101. [CrossRef]

40. Coe, J.V.; Nystrom, S.V.; Chen, Z.; Li, R.; Verreault, D.; Hitchcock, C.L.; Allen, H.C. Extracting Infrared Spectra of Protein Secondary Structures Using a Library of Protein Spectra and the Ramachandran Plot. J. Phys. Chem. B 2015, 119, 13079-13092. [CrossRef]

41. Mei, Y.; Miller, L.; Gao, W.; Gross, R.A. Imaging the distribution and secondary structure of immobilized enzymes using infrared microspectroscopy. Biomacromolecules 2003, 4, 70-74. [CrossRef] [PubMed]

42. Delfino, I.; Portaccio, M.; Della Ventura, B.; Mita, D.G.; Lepore, M. Enzyme distribution and secondary structure of sol-gel immobilized glucose oxidase by micro-attenuated total reflection FT-IR spectroscopy. Mater. Sci. Eng. C 2013, 33, 304-310. [CrossRef] [PubMed] 
43. Yoshida, S.; Koike, K. Lipid and Membrane Dynamics in Biological Tissues-Infrared Spectroscopic Studies. Adv. Planar Lipid Bilayers Liposomes 2011, 13, 1-32.

44. Sailer, K.; Viaggi, S.; Nusse, M. Radiation-induced structural modifications in dsDNA analysed by FT-Raman spectroscopy. Int. J. Radiat. Biol. 1996, 69, 601-613. [CrossRef] [PubMed]

45. Gault, N.; Rigaud, O.; Poncy, J.L.; Lefaix, J.L. Biochemical alterations in human cells irradiated with alpha particles delivered by macro- or microbeams. Radiat. Res. 2007, 167, 551-562. [CrossRef] [PubMed]

46. Zelig, U.; Kapelushnik, J.; Moreh, R.; Mordechai, S.; Nathan, I. Diagnosis of cell death by means of Infrared Spectroscopy. Biophys. J. 2009, 97, 2107-2114. [CrossRef] [PubMed]

47. Ricciardi, V.; Portaccio, M.; Piccolella, S.; Manti, L.; Pacifico, S.; Lepore, M. Study of SH-SY5Y cancer cell response to treatment with polyphenol extracts using FT-IR spectroscopy. Biosensors 2017, 7, 57. [CrossRef]

48. Lipiec, E.; Bambery, K.R.; Heraud, P.; Hirshmugl, C.; Lekki, J.; Kwiatek, W.M.; Tobin, M.J.; Vogel, C.; Whelan, D.; Wood, B.R. Synchrotron FTIR shows evidence of DNA damage and lipid accumulation in prostate adenocarcinoma PC-3 cells following proton irradiation. J. Mol. Struct. 2014, 22, 2860. [CrossRef]

49. Lipiec, E.; Wood, B.R.; Kulik, A.; Kwiatek, W.M.; Dietler, G. Nanoscale investigation into the cellular response of glioblastoma cells exposed to protons. Anal. Chem. 2018, 90, 7644-7650. [CrossRef]

50. Barraza-Garza, G.; Castillo-Michel, H.; De La Rosa, L.A.; Martinez-Martinez, A.; Pérez-León, J.A.; Cotte, M.; Alvarez-Parrilla, E. Infrared spectroscopy as a tool to study the antioxidant activity of polyphenolic compounds in isolated rat enterocytes. Oxid Med. Cell Longev. 2016, 9245150. [CrossRef]

51. Singh, J.K.; Dasgupta, A.; Adayen, T.; Shahmehdi, S.A.; Hammond, D.; Banerjee, P. Apoptosis is associated with an increase in saturated fatty acid containing phospholipids in the neuronal cell line, HN2-5. Biochim. Biophys. Acta 1996, 1304, 171-178. [CrossRef]

52. Delfino, I.; Perna, G.; Ricciardi, V.; Lasalvia, M.; Manti, L.; Capozzi, V.; Lepore, M. X-ray irradiation effects on nuclear and membrane regions of single SH-SY5Y human neuroblastoma cells investigated by Raman micro-spectroscopy. J. Pharm. Biomed. Anal. 2019, 164, 557-573. [CrossRef] [PubMed]

53. Vileno, B.; Jeney, S.; Sienkiewicz, A.; Marcoux, P.R.; Miller, L.M.; Forró, L. Evidence of lipid peroxidation and protein phosphorylation in cells upon oxidative stress photo-generated by fullerols. Biophys. Chem. 2010, 152, 164-169. [CrossRef] [PubMed]

54. Dovbeshko, G.; Gridina, N.Y.; Kruglova, E.B.; Pashchuk, O.P. FTIR Spectroscopy studies of nucleic acid damage. Talanta 2000, 53, 233-246. [CrossRef]

(C) 2020 by the authors. Licensee MDPI, Basel, Switzerland. This article is an open access article distributed under the terms and conditions of the Creative Commons Attribution (CC BY) license (http://creativecommons.org/licenses/by/4.0/). 